\section{In Vitro Propagation of Salvia leucantha Cav.}

\section{T. Hosoki and Y. Tahara}

Laboratory of Vegetable and Ornamental Horticulture, Faculty of Agriculture, Shimane University, Nishikawatsu-cho 1060, Matsue 690, Japan

Additional index words. clonal propagation, tissue culture, $N^{6}$ - benzyladenine, 3 -indolebutyric acid

Salvia leucantha Cav. is a native Mexican perennial plant that has a densely violet-purple, funnel-form calyx and white corolla (Bailey, 1976). The plant is used for cut flowers and in ornamental gardens in Japan. Conventional propagation is by division or cuttings, a method that is too slow for producing many plants in a short time. To overcome this problem, in vitro propagation methods were developed. A frequently used method is to section elongated shoots and promote axillary bud growth. This method is favored because of low somaclonal variation and because many clones are produced from a mother plant (Matsumoto and Yamaguchi, 199 1). Successful mass propagation of yacon (Polymnia sonchifolia Poepp. et Endl.) (Hamada et al., 1990) and edible canna (Canna edulis Ker.) (Hosoki and Sasaki, 1991) have been reported using similar methods. To date, there have been no reports on the in vitro propagation of Salvia spp. The objective of the present study was to establish a rapid propagation method for $S$. leucantha by repeat sectioning of the elongated shoots in vitro.

One-cm-long shoots from the top of $S$. leucantha plants grown in the field of Shimane Univ. were picked on 10 May 1991 andwashed in tap water containing $0.1 \%$ Tween $20(\mathrm{v} / \mathrm{v})$. They were then surface-sterilized with a solution of sodium hypochlorite (active chlorine, $0.6 \%$ ) for $10 \mathrm{~min}$ followed by two rinses in sterile water. After a few basal leaves were cut off, shoot-tip explants $(\approx 3 \mathrm{~cm}$ long $)$ were excised for culture. The explants were placed in test tubes (2 cm in diameter, $15 \mathrm{~cm}$ high) containing $15 \mathrm{ml}$ agar-solidified medium. Test tubes were sealed with Milli Wrap (Japan Millipore Co., Tokyo). The culture basal medium consisted of Murashige and Skoog (MS) major salts and ethylenediaminetetraacetic acid iron salt (Murashige and Skoog, 1962), Ringe and Nitsch minor elements (Ringe and Nitsch, 1968 ), and $2 \%$ sucrose; the medium was solidified with $0.8 \%$ agar after adjusting to $\mathrm{pH}$ 5.6 with $\mathrm{NaOH}$. The basal medium was supplemented with $0,0.1$, or $1.0 \mathrm{mg} N^{6}$ - benzyladenine (BA)/liter. Ten explants were cultured at each BA concentration. Cultures were placed in an incubator maintained at $25 \pm 1 \mathrm{C}$ with $16 \mathrm{~h}$ of

Received for publication 12 Aug. 1992. Accepted for publication 12 Nov. 1992. The cost of publishing this paper was defrayed in part by the payment of page charges. Under postal regulations, this paper therefore must be hereby marked advertisement solely to indicate this fact. light provided by cool-white fluorescent lamps (52 $\mu \mathrm{mol} \cdot \mathrm{m}^{-2} \cdot \mathrm{s}^{-1}$ ).

Eighteen days after culture, shoot-tip explants had grown to 2 to $4 \mathrm{~cm}$ long, irrespective of BA concentration. Shoot counts increased with BA concentration: $1.4 \pm 0.7,3.4$ \pm 1.4 , and $3.9 \pm 1.7$ (mean \pm SD) with $0,0.1$, and $1.0 \mathrm{mg} \mathrm{BA} /$ liter, respectively. Increasing BA clearly promoted multiple-shoot formation due to the release of axillary buds. For further shoot multiplication (the first subculture), shoots were divided at the internodes into sections containing at least one node. The number of shoot sections obtained per explant was $2.9 \pm 1.4,5.0 \pm 0.6$, and $5.0 \pm 2.1$ (mean \pm $\mathrm{SD}$ ) in the medium with $0,0.1$, and $1.0 \mathrm{mg} \mathrm{BA} /$ liter, respectively. Thus, more shoots were obtained in BA-supplemented media. Shoot sections obtained from each BA concentration were recultured in the corresponding $\mathrm{BA}$ concentrations. Thirteen days after culture, axillary buds had grown to 2 to $4 \mathrm{~cm}$ long. Again, these shoots were sectioned for further multiplication. Four subcultures (shoot sectionings) were conducted at $\approx 20$ - day intervals. Total shoot counts increased with BA concentration (Table 1). Shoot length decreased slightly with increasing BA concentration. Fourty-seven percent of the shoots from medium supplemented with $1 \mathrm{mg}$ BA/liter was vitrified. Vitrificationrate was $5 \%$ in $0 \mathrm{mg}$ and $10 \%$ in $0.1 \mathrm{mg} \mathrm{BA} /$ liter. Higher BA concentrations frequently induce vitrification, and the vitrified shoots might not survive ex vitro conditions (Ziv, 1991). Therefore, using $1 \mathrm{mg}$ BA/liter is not advisable, although it yielded the most shoot sections. Medium supplemented with $0.1 \mathrm{mg} \mathrm{BA} /$ liter seems optimum to obtain a maximum number of normal shoots, although a concentration between 0.1 and $1 \mathrm{mg} /$ liter was not tried. Repeated sectioning at 20 day intervals could theoretically yield $(4.2 \times$ $0.9)^{18}$ new shoots from one shoot tip in 1 year, where 0.9 represents a rate of nonvitrified normal shoots. This multiplication rate is by far more rapid than conventional propagation by division or cutting for $S$. leucantha.

The chance for somaclonal variation likely

Table 1. In vitro multiplication of Salvia leucantha shoots by repeated shoot sectioning.

\begin{tabular}{|c|c|c|c|}
\hline \multirow{2}{*}{$\begin{array}{l}\mathrm{BA} \\
\text { (mg.liter }{ }^{-1} \text { ) }\end{array}$} & \multicolumn{2}{|c|}{ Shoot } & \multirow{2}{*}{$\begin{array}{l}\text { No. sections from } \\
\text { shoot sectioning }\end{array}$} \\
\hline & Count (no.) & Length $(\mathrm{cm})$ & \\
\hline 0 & $1.8 \pm 0.4$ & $2.7 \pm 0.6$ & $3.6 \pm 0.7$ \\
\hline 0.1 & $2.5 \pm 0.8$ & $2.5 \pm 0.6$ & $4.2 \pm 0.7$ \\
\hline 1.0 & $3.4 \pm 0.6$ & $2.2 \pm 0.3$ & $4.7 \pm 0.8$ \\
\hline
\end{tabular}

${ }^{\bar{z}}$ Mean \pm SD of initial culture and four subcultures. a $15 \mathrm{~N}-8 \mathrm{P}-17 \mathrm{~K}$ water-soluble fertilizer $(2.5$ $\mathrm{g} \cdot$ liter $\left.^{-1}\right)$ three times weekly. The ambient temperature was $\approx 20 \mathrm{C}$ (day and night). Light levels were the same as for in vitro culture. Rooted plantlets were acclimatized by gradually opening the film day by day; they were completely uncovered after 19 days. All plants were established without any signs of water stress. Plantlets were then transferred to a 23,940- $\mathrm{cm}^{3}$ wooden box containing 2 sandy loam : 1 bark $(\mathrm{v} / \mathrm{v})$. Plants were grown in a greenhouse at $\approx 30 / 20 \mathrm{C}$ (day/night), watered daily, and fertilized with $2.0 \mathrm{~g}$ granulated compound fertilizer $(13 \mathrm{~N}-10 \mathrm{P}-12 \mathrm{~K})$ (Neocode 302 type; Mitsui Co., Ohsaka, Japan) per plant. Two months after transfer to the greenhouse, all plants flowered normally. In conclusion, in vitro shoot multiplication of $S$. leucantha may be accomplished from shoot-tip culture and axillary bud growth promoted by repeated shoot sectioning in MS medium supplemented with $0.1 \mathrm{mg} \mathrm{BA} / \mathrm{liter}$.

\section{Literature Cited}

Bailey, L.H. 1976. Hortus third. Macmillan, New York.

Hamada, M., T. Hosoki, and Y. Kusabiraki. 1990. Mass-propagation of yacon (Polymnia sonchifolio) by repeated node culture. Plant Tissue Culture Let. 7:35-37.

Hosoki, T. and H. Sasaki. 1991. In vitro propagation of Canna edulis Ker. by longitudinal shoot-split method. Plant Tissue Culture Let. 8:175-178.

Matsumoto, K. and H. Yamaguchi. 1991. Plant clonal propagation, p. 106128. In: H. Yamaguchi (ed.). Bioengineering science. vol. 5. Shoukabou Press, Tokyo. dium for rapid growth and bioassays with tobacco tissue culture. Physiol. Plant. 15:437-497.

Ringe, F. and J.P. Nitsch. 1968. Condition leading to flower formation on excised Begonia fragments cultured in vitro. Plant Cell Physiol. 9:639-652.

Ziv, M. 1991. Vitrification: Morphological and physiological disorders of in vitro plants, p. 4569. In: P.C. Debergh and R.H. Zimmerman (eds.). Micropropagation technology and application. Kluwer Academic, London. would be low, because multiplication was conducted only by release of axillary buds in themedium with low BA concentration. Shoots $\approx 2.5 \mathrm{~cm}$ in length were transferred to basal medium supplemented with $0,0.1$, or $1 \mathrm{mg} 3$ indolebutyric acid (IBA)/liter for rooting. Eleven to 12 shoots were treated at each IBA concentration. Twenty days after transfer, the rooting rate was $>90 \%$, and the mean root count per shoot was 5.1 to 6.3 , irrespective of IBA concentration. Thus, IBA was not necessary for rooting. Ten rooted plantlets were planted randomly in a plastic tray containing sandy loam and covered with a plastic film. Shoots were watered daily and fertilized with

Murashige, T. and F. Skoog. 1962. A revised me- 